\title{
EVALUATION OT COMBINED INACTIVATED RESPIRATORY VIRUS VACCINE PNEUMO-4 IN PREGNANT COW DAMS
}

\author{
El-Sabbagh*, M. M. A.; El-Sawalluy"*, A. A. : \\ Samira Sald" and Ghaly*, H. M. \\ Veterinary Serum and Vaccine Research Instltule. Abاasia, Calro \\ "-Department of Infectlous DIseases, Fac. Vet. Med. . Mansoura Unversily.
}

\begin{abstract}
Evaluation of combined inaclluated respiralory virus vaecine (Pnetuno-4) aggainst IBR, BVD. PI.3 and BRSV in calle was achteved in private farm localed al Dommiallo Goventorale (El-Basaleen Farm). Tuxenty apparently heallhy pregnant conss ukre ver cinated 2 doses by intramuscular injection of $5 \mathrm{ml}$ of the vacclne. 2 weeks apart at late" stagc of pregnangy (1-3 months before delivent) and len pregnant cows whe lefl as urlexccinated control. The antibody levels worc estlmated quantilatluely using SN and ELISA technifues for both cows and their of-springs.

Inumumized Dants gave ofT-springs IBR, BVD, PI-3 and BRSV anlibod!y whlhin Ilu' prolectlue level up to 4 and 6 months of age according to the time of deliven/ post vacri nation
\end{abstract}

\section{INTRODUCTION}

Respiralory discases and the bovine mucusal disease complex are of considerable erominic Importance to the cattle Industry. Routlne Inoculation of cattle ivith ellher Individual (o) ('ombined live altenuated viral vacelnes prepared wIth IBR. BVD. PI-3 and BRSV viruse's are used widely for prophylaxls agalnst these diseases. However, Inoculation of pregnant callle with allen. thated vaccines is discouraged since this practice may lead to abortion (Rosner, 1968). liurllkemore. BVD virus can pass the placenta and infect the fetus at all stages of gestation (Radoetitis et al.. 2000).

Abortion. cerebellar hypoplasla, oeular lesions still births, wcakness and diarrhoca orcurrcl parisularly with infection in the first hall of gestation. For thesc rcasons, vaccination of suscep)IJble pregnant cows with inactivated virus vaceines is usually recommended at any stage of prcknancy in cow call operations of both the beel and dalry Industrics where cow miglil bx in ill 
stages of pregnancy (Ellls et al., 1990 and Donkersgoed 'et al., 1991).

Pneumoententls problem in young calves is no longer be regarded as occurring sporadually with the Increase In intenslve systems of managcrnent in Egypt. The viral agent causing respliritory diseases in Egypt Include Infectious bovine rhinotracheltis (IBR). bovine viral diaithocy (BVD). paralnfluenza-3 (PI-3) and bovine resplratory syncytlal (BRS). Occurrence of pneumoenleritis syndrome is most frequent and sever within the calves younger than 3 inonths and inversely related to the level of naternal antibodies (Kctmman, et al., 1988).

It was ret... ded tliat effeetluc lactogenic Immunity against pneumoenteritis of viruse's could be achleved by ingestion of colostrum containing adequate levels ol protcclive antibodies (Joseph et al., 1973 and Ells et al., 1998).

The alm of this sludy was to evaluate the immune response in pregnant cows (last stage) ats well as to follow up the acquired colosiral immunity of thetr calves for 6 months aller parturll lon under field condillons.

\section{MATERIAL AND METHODS}

1. Cows : Thirty apparently healthy pregnant cows aged 4-5 years and of alxut $500 \mathrm{~K}_{\mathfrak{K}}[3 . \mathrm{W} 1$. Proved io be negative to IBR BVD . PI-3 and BRSV antllodles. were used lor evaluation of combined Inaetivated respiratory virus vaeelne (Pneurno-4) at Basateen Farm in Dommiatla Guvernorate. 'These animals were divided into two groups.

Group (1): Consists of 20 cows vaccinated with pneumo-4 vaccine in(rimusculiarly (I/M) with 2 doses 2 wceks apart.

Group (2) : Consists of 10 cows were left as unvacelnated eontrol.

\section{Viruses:}

a. IBR virus: Alou-Hammad strain (10-7.5 $\left.\mathrm{TCID}_{50} / \mathrm{ml}\right)$.

b. P1-3 virus: Stralrı $45\left(10^{-8} \mathrm{TCID}_{50} / \mathrm{ml}\right)$.

c. BVD virus: Iman straln $\left(10^{-6.5} \mathrm{TCID}_{50} / \mathrm{nI}\right)$.

d. BRS virus: Strain 375L (10-6.5 $\left.\mathrm{TClD}_{50} / \mathrm{ml}\right)$.

These viruses stralns were kIndly supplied from Rinderpest like diseases Vaecinc Produetion Department Serum and Vaeclne IResearch Instltutc. Abbassla. Cairo.

3. Vacelne : Comblued Inaetlvaled resplratory vilus vacelne containing bovine virus diarrhoca (BVD). : afeetlous bovine rhlnotrachelts (IBR), parainfluenza-3 (PI-3) and bovinc. respiralo- 
ry syncytlal virus (BRSV) was prepared locally in Rnderpest L/ke Disease Depl.. Volitrinary Sorum and Vaccine Rescarch Instltute, Abbasla, Calro.

4. Cell culture: Madin Darby Bovine Kidney (MDBK) cell line culture which tested to bi frce from non-cytopathic (NCP) of BVD. MD virus by fluorescent test (Marcus and Moll, 1968) wils used in this sludy.

5. Serological test :

a. The Micro-scrum Neutralization Te;t (MSNT): Il was performed according to Rossl and KJesel (1971).

๖. Indirect ELISA lechnique; Il was Larried out according to Edwards and Newman (1985) fior detcetion ol antibodics agalnst BVD. IBR. PI-3 and BRSV viruses.

\section{Sampling :}

Blood samples were taken [rom cows beforc inoculalion of the first dose of llue valcinc (0 lime) then prior $1 .$. . Idministration of the second dose of the vaceine $(2,3,4.6$. 8 wreks post vacrina(ion) and bctore parturition. Also blood samples were similarly coliccted from unvaccinated r'uws at the sanuc Intervals. Also blood samples werc collected from the new born calves all 1 week posit delivery then at 1, 2, 3. 4, 5, 6 month post dllevry. Sera werc separated by centrilugation and kept al $-20^{\circ} \mathrm{C}$ for antibody assays.

\section{Clinical eramination:}

The vaccinalcd cows and unvacclnated control group as wcll as thelr off-springs were ob-

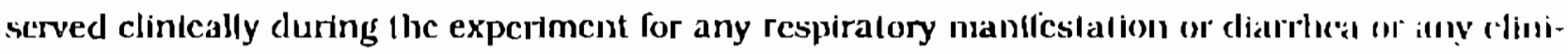
cal abnormalities during the experiment. The body temperature of the pregitant cows wils recorded befurc and deily after vacelnatlon for one weck.

\section{RESULTS AND DISCUSSION}

Bovine respiratory disease complex is one of the selious infectinus multilartortal problems which rause high economic losses due to mortality, therefore it is Important to vaccinite all sussceptible animals with a sale, potent and highly immunogenic vaccine. In Esypt. recently "Pne'tmo 4" was introduced to vacelnation program of anlmals. So. this field experdinent was performed to evaluale of a combined Inactivated respiratory virus vaccine "Pneumo 4" in pregnanl cows ind their olf-springs.

All cows In group I vaccinated with pneumo 4 in the late stage of gastation period and lheir olfspring were noimlal during the experimental period (6 Months) and did nol exlibiblt any rise in 
body temperature or showed any signs of respiratory disease. This might be contribulcd lo llic safely of the locally produccd vaccine "Pneumo 4 ".

Stuclies on the immunogenicity and duration of the tmmunc response following immunizallion of pregnant cows with locally produced "Pneumo 4" under field condition as clenonstrated in Tables (1\&2).

The neutraltzing antibudles started to increase following vacclnation at 3 weeks posit vaccination (The protective level) and increased to maximial level at 8 weeks post vaccination as shown in Table [1].

The results of inaternal immunity of calves born to vaccinaled preginant corvs and their incontact born to unvaccinated control cows are shown in Tables (3\&4). The titer of the off-sprillys horn to vaccinated cows arc inatched with the ther of thelr dams at the lime of parturition. Ilicse results are In agrecnent witl that obtained by Baz (1975) who reported that calves get the same litcr of' antibodies or higher than their dams.

The antibodies gaaclually decreased toward the $\mathbf{s}$ montlss post parturition and reaclied It) the minhmal protcctive lcvel of immunily. 'These results agreed with that oblatned by Joseph et a. (1973), : . skka and Edward Alvin (1990), Donkerogoed et al. (1891) who conclucleel thal the matcrnal antlbodles of eatlle calves that were devcloped as a result of varcinatinn of llocir dams with killed vaccine containing BVD. IBR, 11-3 and BRSV may persist fur 6 montlıs.

Cattle calves that were clelivered at 3 months of vaccination of thet dans renained protered till the fourth month as oblained by Brar et al. (1978) who eoncluded that passive colosiril .mlibodles lost one half of thelr remaining antibody titre cucry 2 I days and scrologically responiled to vacclne at a tinie when inatemal antibody titrc was beliveen 1:96 and 1:20 (aboull $31-7$ months]. Thus, the prescnt studies inclicatcd the maternal antibodles in calves remalned ivilidu llic protectlve Icvel from 3-6 months when Il cones from dams vaccinaled with BVD lnacllvalled vaccine at the last gestation perlod of pregnancy.

Ellis et al. (1996) found lliat after Inoculation of pregnant cows witl Cattle Master-4 discovered that immunlzation of young calves with Catte Master-4 one shot on day 10 of lifi dicl not result in the production of Inereased serum lcvel of antibudies and it may be altribuled io at blocking elfect of maternal antibody or an age elfect on the response to the vaceinc

Under natural fleld conditlons in this experiment, the obtained results showed that there wits only double fold increase betwecn the incan tities of calves born from vacchiated and nonvacelnated dams. This may be atlnibuted to the time of delivery in some dams. Also. some calves may not recelved the colostrun fron their dams at the optimun time post parturliton and il 
should be inentloned this farn was suffering from bad hygienic measuics.

The rcsults of clintcal examination after varcination and seroconversion indicate thes the focally produced pneumo 4 can be safcly uscd to immunizc pregnant coivs to control the infertikss in new born calves results from BVD, IBR, PI-3 and BRSV viruses. 
Table 1: Serum neulralizing antibody litre in pregnant cows post vaccination wilh combined inactivaled respiralory virus vaccine (Pneumo-4).

\begin{tabular}{|c|c|c|c|c|c|c|c|c|c|c|c|c|c|c|c|c|c|c|c|c|c|c|c|c|}
\hline \multirow{3}{*}{$\begin{array}{l}\text { Animel } \\
\text { groups }\end{array}$} & \multicolumn{24}{|c|}{ Log 10 serum neutralizing antibody titre in pregnancy } \\
\hline & \multicolumn{6}{|c|}{$\begin{array}{c}\text { BVD } \\
\text { Weeks Post Vaccinatlon }\end{array}$} & \multicolumn{6}{|c|}{$\begin{array}{c}\text { IBR } \\
\text { Weeks Post Vaccination }\end{array}$} & \multicolumn{6}{|c|}{$\begin{array}{c}\text { P1-3 } \\
\text { Woeks Posl Vaccinallon }\end{array}$} & \multicolumn{6}{|c|}{$\begin{array}{c}\text { BAS } \\
\text { Weekg Post Vaccinalion }\end{array}$} \\
\hline & 0 & 2 & 3 & 4 & 6 & 8 & 0 & 2 & 3 & 4 & 6 & 8 & 0 & 2 & 3 & 4 & 6 & 8 & 0 & 2 & 3 & 4 & 6 & $B$ \\
\hline vaccinated goup & 0,4 & 0.4 & 0.9 & 1.15 & 1.6 & 1.7 & 0.5 & 0.55 & 1.0 & 1.25 & 1.7 & 1.85 & 0.6 & 0.7 & 1.1 & 1.45 & 1.85 & 1.95 & 0.6 & 0.65 & 0.9 & 1.3 & 18 & 1.8 \\
\hline Contral group & 0.65 & 0.95 & 0.55 & 0.3 & $\cdot$ & - & 0.9 & 0.95 & 0.85 & 0.4 & . & • & 0.85 & 0.85 & 0.9 & 0.3 & . & & 0.6 & D.B & 065 & 0.45 & . & \\
\hline
\end{tabular}

Table 2 : ELISA mean antibody tilres against BVD, IBA, PI-3 and BRS antigen in sera of vaccinaled cows

\begin{tabular}{|c|c|c|c|c|c|c|c|c|c|c|c|c|}
\hline \multirow{3}{*}{$\begin{array}{l}\text { Animal } \\
\text { groups }\end{array}$} & \multicolumn{12}{|c|}{ Log 10 serum neutralizlng antlbody Iltre in pregnancy } \\
\hline & \multicolumn{3}{|c|}{$\begin{array}{c}\text { BVD } \\
\text { Weoks Pogt Vaccination }\end{array}$} & \multicolumn{3}{|c|}{$\begin{array}{c}\text { IBR } \\
\text { Waeks Post Vaccination }\end{array}$} & \multicolumn{3}{|c|}{$\begin{array}{c}\text { P1-3 } \\
\text { Weeks Pogt Vaccination }\end{array}$} & \multicolumn{3}{|c|}{$\begin{array}{c}\text { BAS } \\
\text { Wooks Pogl Vaccinalion }\end{array}$} \\
\hline & 0 & 2 & 4 & 0 & 2 & 4 & 0 & $<$ & 4 & 0 & 2 & 4 \\
\hline vaccinalod goup & 0.4 & 1.25 & 1.8 & 0.65 & 1.4 & 1.85 & 0.9 & 1.5 & 1.80 & 0.6 & 1.2 & 1.6 \\
\hline Conirol group & 0.55 & 0.4 & 0.35 & 0.4 & 0.0 & 0.5 & 0.75 & 0.5 & 0.4 & 0.65 & 0.6 & 0.35 \\
\hline
\end{tabular}


Table 3 : $\log _{10}$ serum neutralizing antibody titre in vaccinated, control cows and their offsprings.

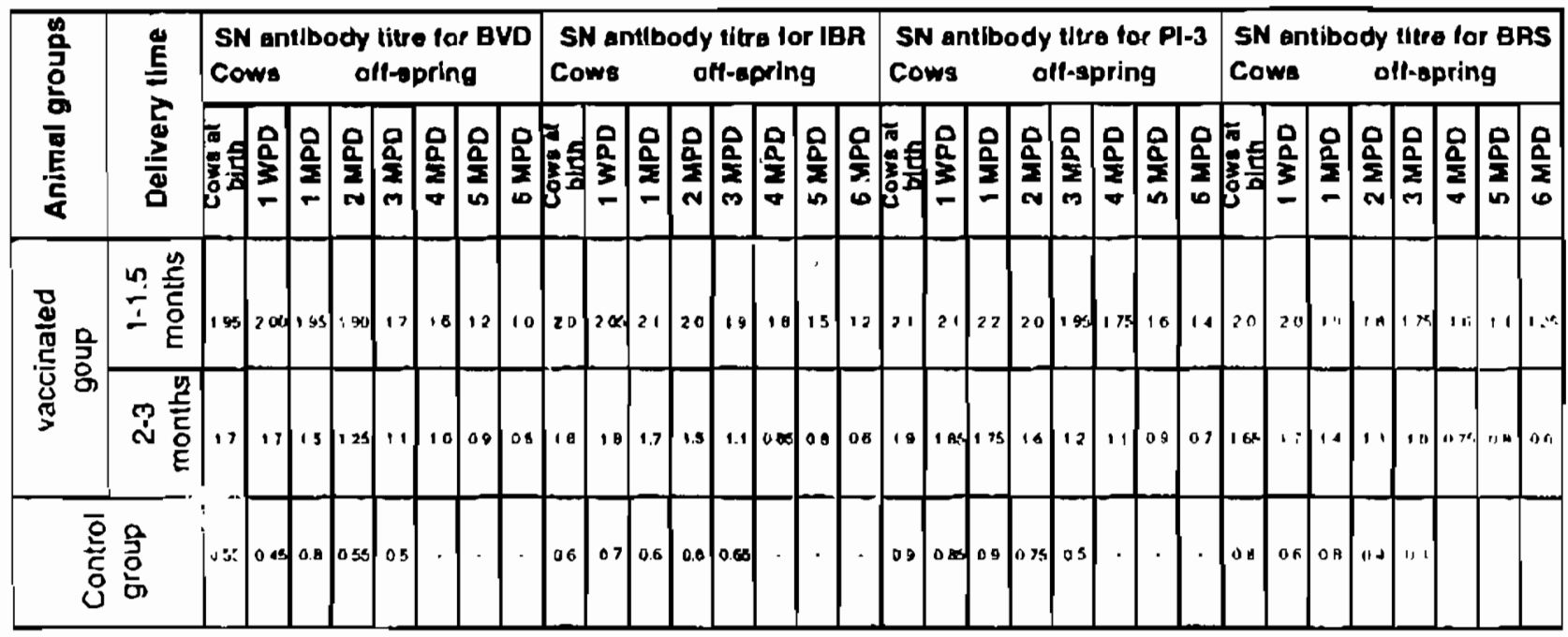

WPD : Weeks Post Dellvery

MPD : Manths Post Dellvery.

Table 4 : EISA mean antibody liters for BVD, IBR, PI-3 and BNS in sera of calves trom vaccinaled and control dams posl vaccination.

\begin{tabular}{|c|c|c|c|c|c|c|c|c|c|c|c|c|c|c|c|c|c|c|c|c|c|c|c|c|c|c|c|c|}
\hline \multirow{2}{*}{ 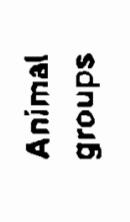 } & \multicolumn{7}{|c|}{ DVD } & \multicolumn{7}{|c|}{ IBR } & \multicolumn{7}{|c|}{ PI-3 } & \multicolumn{7}{|c|}{ GAS } \\
\hline & $\begin{array}{l}0 \\
0 \\
3 \\
-\end{array}$ & $\begin{array}{l}0 \\
0 \\
\frac{2}{3} \\
-\end{array}$ & $\begin{array}{l}0 \\
\frac{0}{2} \\
\text { v }\end{array}$ & $\begin{array}{l}0 \\
\frac{a}{2} \\
\text { n }\end{array}$ & $\begin{array}{l}0 \\
\frac{1}{x} \\
\frac{0}{x}\end{array}$ & 品 & $\begin{array}{l}0 \\
\frac{a}{2} \\
0\end{array}$ & $\frac{0}{\frac{0}{3}}$ & 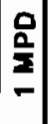 & $\begin{array}{l}\text { Q } \\
\frac{2}{2} \\
\text { N }\end{array}$ & $\begin{array}{l}0 \\
\frac{0}{2} \\
\text { n }\end{array}$ & $\begin{array}{l}\frac{0}{2} \\
\frac{2}{2} \\
\frac{1}{2}\end{array}$ & $\begin{array}{l}0 \\
\frac{2}{2} \\
\text { in }\end{array}$ & $\begin{array}{l}0 \\
\frac{1}{2} \\
0\end{array}$ & $\begin{array}{l}0 \\
\frac{a}{3} \\
\sigma\end{array}$ & $\begin{array}{l}0 \\
\frac{2}{2} \\
-\end{array}$ & $\begin{array}{l}Q \frac{a}{2} \\
\frac{2}{2}\end{array}$ & $\begin{array}{l}0 \\
\frac{a}{2} \\
\text { m }\end{array}$ & $\frac{0}{2}$ & 量 & $\begin{array}{l}a \\
\vdots \\
0 \\
0 \\
0\end{array}$ & $\begin{array}{l}0 \\
\frac{0}{3} \\
r\end{array}$ & $\begin{array}{l}\text { 을 } \\
\text { 을 } \\
-\end{array}$ & $\begin{array}{l}\frac{0}{2} \\
\frac{a}{2} \\
\text { v }\end{array}$ & 虽 & $\begin{array}{l}0 \\
a \\
\vdots \\
0\end{array}$ & $\begin{array}{l}0 \\
\frac{2}{2} \\
\text { in }\end{array}$ & $\begin{array}{l}0 \\
\frac{0}{5} \\
0\end{array}$ \\
\hline 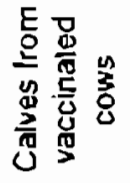 & 175 & 17 & I t 65 & 13 & 118 & 10 & 0.9 & 185 & $105 \mid$ & 17 & o 69 & 14 & 12 & 0.0 & 12 & 20 & 19 & | 175 & 13 & 12 & 10 & 1es & 18 & $1 \in A$ & 153 & 1.25 & On & lase \\
\hline 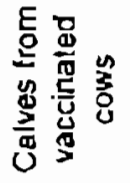 & $10 \mathrm{~B}$ & $0 \& 4$ & 101 & 0.6 & & & $v$ & ars & 0.05 & 0.8 & 0.45 & & . & & 08 & 10 & 0.85 & 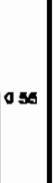 & & & & $0 \times 5$ & oos & 075 & 06 & & & \\
\hline
\end{tabular}

WPD : Weeks Post Delivery

MPD : Monthe Poat Dallvery. 


\section{RETERENCES}

Bez. T. 1. (1975) : Isolation, characterizatlon and serological sludles on BVD-MD) virus in Éfypt. Ph.D. Thesis, Fac. Vet. Med., Cairo Unlv.

Brar (1978) : Maternal immunlly to bovinc rhinotracheilis and bovine viral diarihoea viruses. An. J. Vet. Res., 39 (2): 24 i-244.

Donkerbgoed, J. Van; Hurk, J. Van Den; MeCartney, D. and Harbard, R. J. (1991) : Cul1paralive serologlcal responses in calves to cight commercial vaccines against infectious bovine ihinotracheltls, paraln huenza-3, bovine respiralory syncylial and bovine viral dialrloca viruses. Cand. Vet. J., 32 (1 1): 727-733.

Edwards, S. and Newman, R. H. (1985) : Deteclion of antibodles to BH-4 by ELISA. V('t. Mic'(ubiol., 10: 149-154.

Ellis, J. A.; : vis, W. C.: Tolens, L. and Pratt, D. L. (1990) : Cilnical and inmumulogical respoli.e: of cattle to administralion on a vaccine contalning modllied live BRSV. J. Am. Vet. Med. Assoc., 196 (4): 583-589.

Euls, J. A.; Hassard, L. E. and Lertesc, v. 5. (1996) : The efTect of perinatal vatecination on humoral and cellular inmnune responses in cows and young calves. J. Am. Vel. Macl. Arsoc.. 208: 393-400.

Joseph, R.; Kolar, J.; Schechmelster, I. L. azid Louls, E. Strack (1973) : Fleld experiments with formalin-kllled vlrus vaccinc contalnlug mfectious bovine rhinofiacheilis, lovinl vlral diarthoca and paradnflucora-3. Am. J. Vel. Res.. :34 (I I): 1469)-I 171.

Kumman, T. G.; ZImmer. G. M.; Wcstenbrink, F.; Mars, J. and Van Lecuwen, E. (1988) : Epidemiological study of bovine resplratory syncylial virus infectlons in calves. Influenee of matemal antibodies on the outcome of diseasc. Vet. Rec., 123: 104-109.

Marcus, S. J. and Moll. T. (1968) : Adaptation of bovine viral dlarthocat virus to Madin l)arly bovine kidncy cell line. All. J. Vet. Res.. 29 (4): 817-819.

Radostlts, O. M.; Gay, C. C.; Blood, D. C. and 1lincluclif, IS. W. (2000) : Velerinary Medie'ine' $\Lambda$ text book of the discases of callle. shecp pigs, goats and horses. 91h Edition. Batilicr. Tindall. England, London.

Rosner, S. F. \{1968\} : Complications following vaccination of calle against Inlectious bovine 1hlnotracheitts and paralnthenza-J. J. Am. Vcl. Med. Assoc., 52: 898-901.

Rossi. C. R. and Kiesel, G. K. (1971) : Microlltre lests for detecting antlbocly in bisvine scrum to paralnlluenza virus, infeellous bovine rhinotracheitis virus and bovine viral diatrhoea 
vitus. Microblol. 22: 32-36.

Stokka, G. L. and Edwards Alvin, I. (1990) : Revacelnalion of slitessed calves ivill a mulliple polyvalent vaecine (IDIR, PI-3. BIRSV). Agrt. Pract.. 11 (5); 18-20. 


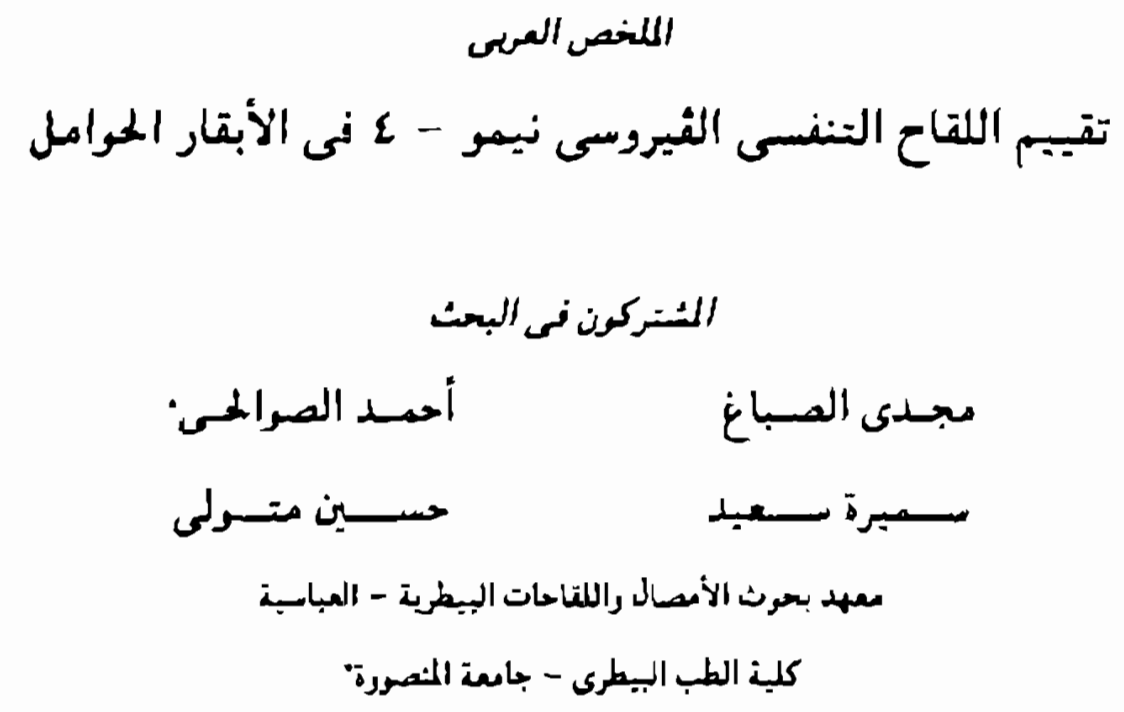

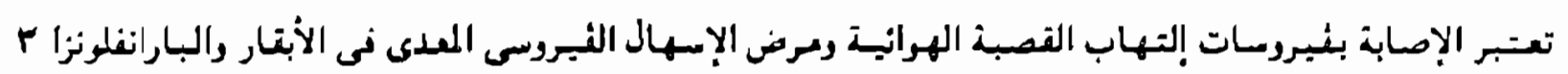

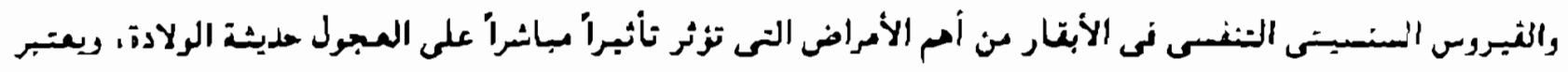

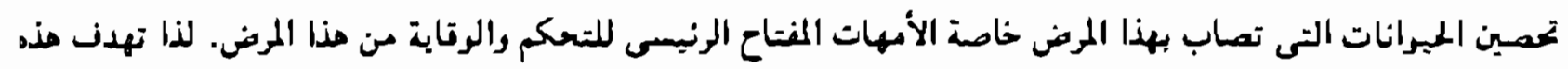

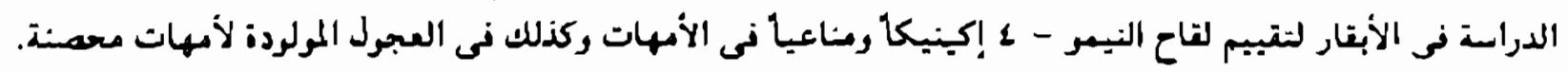

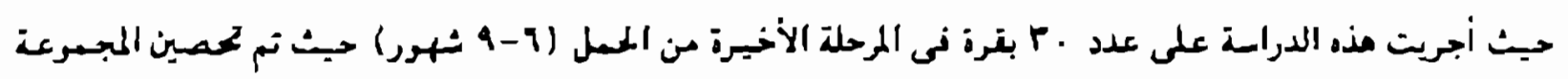

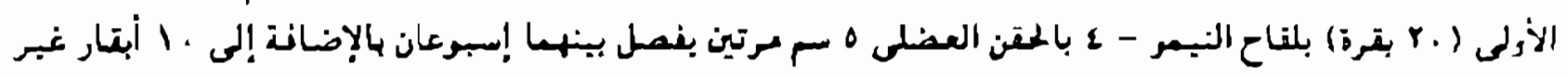

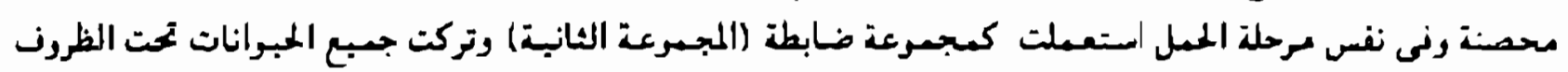

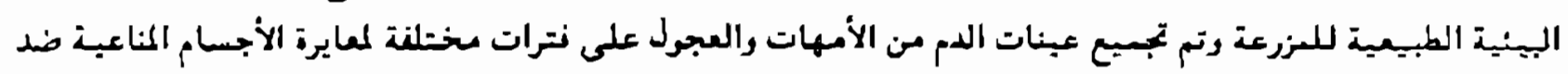

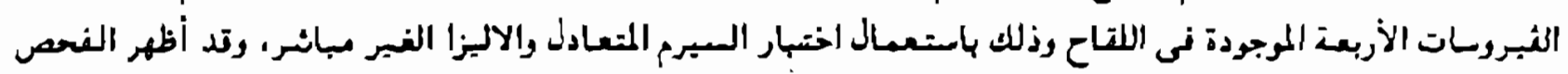

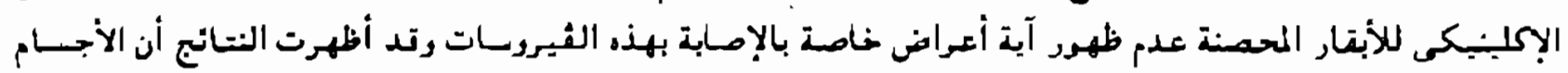

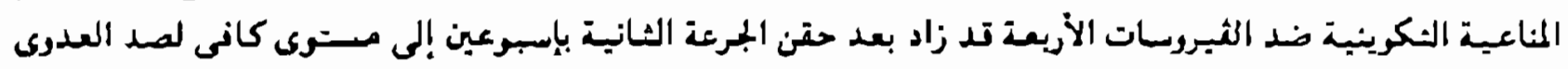
الطبيعية.

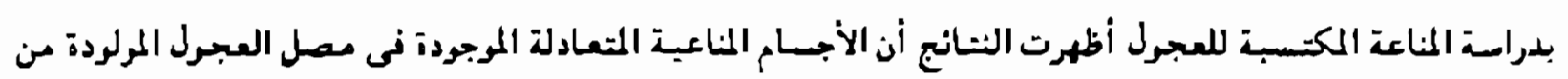

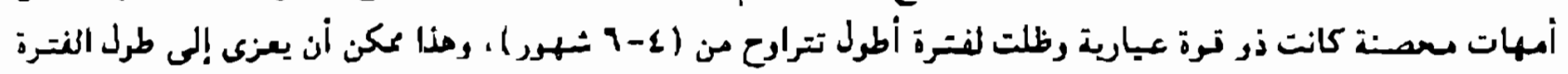

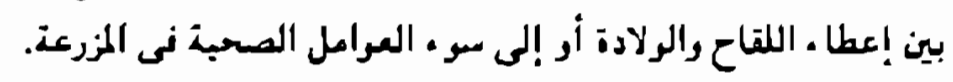

